TAPROBANICA, ISSN 1800-427X. November, 2021. Vol. 10, No. 02: pp. 132, pl. 30.

(C) Research Center for Climate Change and Department of Biology, Faculty of Mathematics \& Natural Sciences, University of Indonesia, Depok 16424, INDONESIA.

http://www.taprobanica.org

https://doi.org/10.47605/tapro.v10i2.265

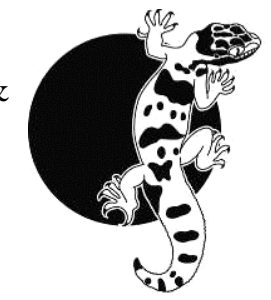

\section{On the occurance of crowned river turtle, Hardella thurjii in Gujarat, India}

The crowned river turtle, Hardella thurjii (Gray, 1831) is widely distributed from Pakistan to Bangladesh, and possibly in western Myanmar (Das \& Bhupathy 2009). It prefers the middle and lower reaches of the northern river systems on the Indian subcontinent, comprising the Indus, Ganga, Brahmaputra, and their tributaries (Das \& Bhupathy 2009). The species is classified as Endangered, but nationally remains a poorly protected species under the Indian Wildlife Protection Act (Ahmed et al. 2021). This communication presents the first photographic evidence of the crowned river turtle, from Gujarat State, India. It was previously reported from North Gujarat two decades ago (Sharma 2000), but without any evidence.

On 25 March 2021, a live healthy turtle (body weight $550 \mathrm{~g}$; Straight carapace length $11.8 \mathrm{~cm}$ ) was deposited at a wildlife rescue centre in Vadodara by a local. The turtle was found while it was roaming on the road near Harni $\left(22^{\circ} 20^{\prime} 29.95^{\prime \prime} \mathrm{N}, 7^{\circ} 13^{\prime} 8.24^{\prime \prime} \mathrm{E}\right)$, located between two freshwater bodies, in the suburbs of Vadodara City. Upon close examination it was identified as a subadult female of Hardella thurjii. The specimen (Fig. 1) had a dark-brown carapace with grey-black keel, costo-marginal juncture marked with an orange-yellow band; plastron yellow with a large black blotch on each scute; head covered with four yellow stripes: (i) on top of the head, (ii) from above the ear-drum and eye up to the snout, (iii) from below the eye to the nostrils, and (iv) on the angle of jaws.

The water bodies in Harni are being reduced in area and degraded by artificial alterations, due to the modifications and developments carried out by local urban development authority (Vyas 2015). Due to the proximity of these wetlands to the rescue site, we assume that the turtle's origin can be attributed to its seasonal migration from one water body to another. It is also possible that the specimen reported here might be an escaped individual from a nearby captive facility. Literature surveys reported 16 species of Chelonians in the Gujarat, including an exotic species, but the status of five of them has not been recently evaluated (Patel \& Vyas 2019).

\section{Acknowledgements}

We thank Deputy Conservator of Forest, Forest Range Officers and the staff at Forest Department of Gujarat for their support.

\section{Literature cited}

Ahmed, M.F., P. Praschag, and S. Singh (2021). Hardella thurjii. The IUCN Red List of Threatened Species: e.T9696A3152073.

Das, I. and S. Bhupathy. (2009). Hardella thurjii (Gray 1831). Conservation biology of freshwater turtles and tortoises. A compilation project of the IUCN/ SSC tortoise and freshwater turtle specialist group. In: Rhodin, A.G.J., P.C.H. Pritchard, P.P. van Dijk et al. (eds.). Chelonian Research Monographs.

Patel, H. and R. Vyas (2019). Reptiles of Gujarat, India: Updated checklist, distribution and conservation status. Herpetology Notes, 12: 765-777.

Sharma, R.C. (2000). Reptilia. In: Alfred, J.R.B. (ed.). Fauna of Gujarat (Part 1). Vertebrates: 243-298.

Vyas, R. (2015). Status of Ganges Soft-shell Turtle Nilssonia gangetica amidst deplorable scenarios in urban wetlands of central Gujarat State, India. Reptile Rap, 17: 3-12.

Vyas, R. and H. Singh. (2004). Biodiversity survey of Gandhisagar Reservoir, Madhya Pradesh. Zoos' Print Journal, 19(7): 1525-1529.

Submitted: 22 Sep. 2021, Accepted: 15 Nov. 2021 Section Editor: Thasun Amarasinghe

$$
\text { Raju Vyas }{ }^{1} \& \text { Harshil } \text { Patel }^{2}
$$

${ }^{1}$ 1-Sashwat Apartment, BPC Road, Nr. Splatter Studio, Alkapuri, Vadodara 390007, Gujarat, India ${ }^{2}$ Department of Biosciences, Veer Narmad South Gujarat University, Surat 395007, Gujarat, India E-mail:harshilpatel121@gmail.com 


\section{Plate 30}

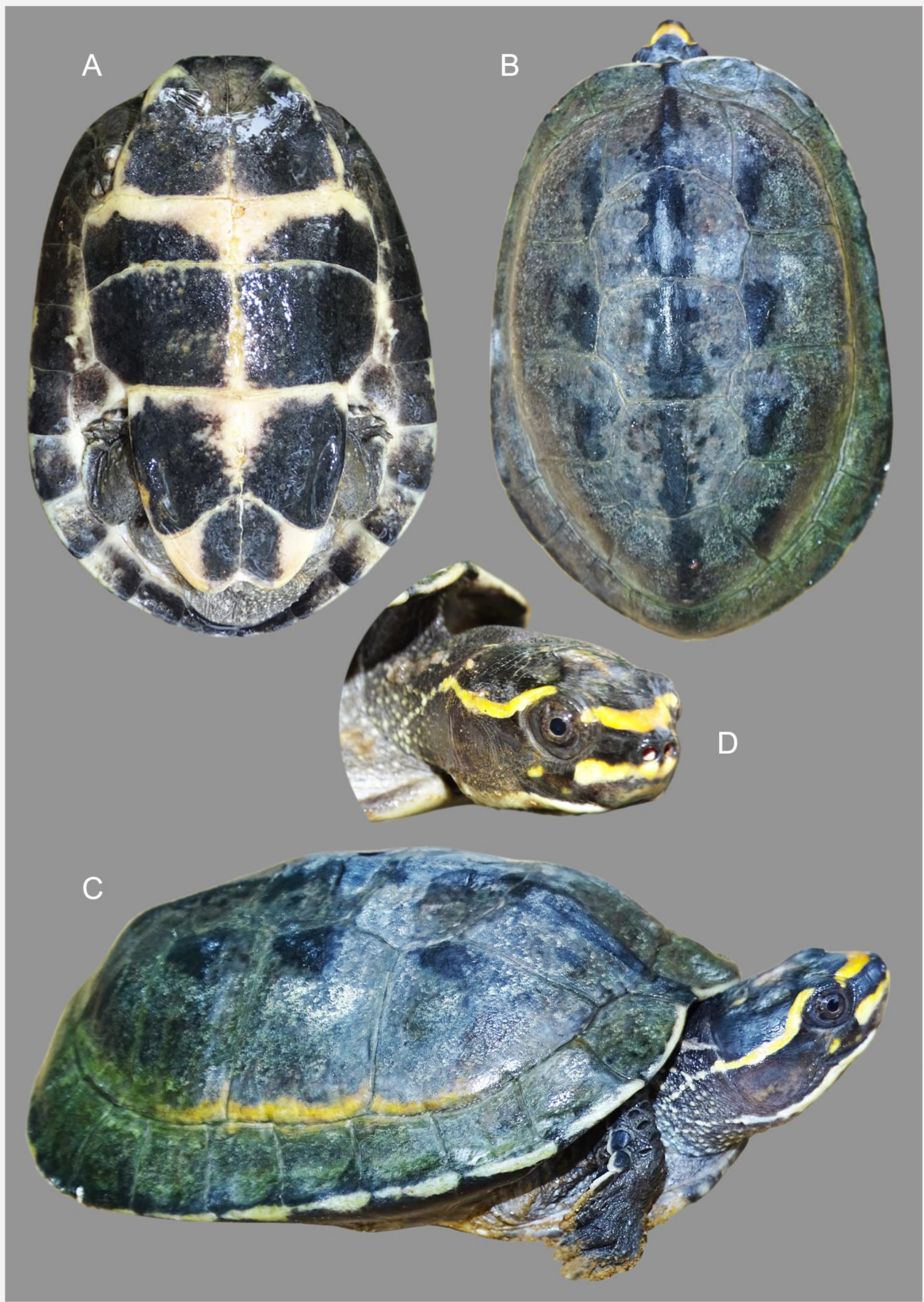

Figure 1. Hardella thurjii from from Harni, Vadodara, Gujarat, India: (A) plastron, (B) carapace, (C) lateral view of the turtle, and (D) frontolateral view of the head 